\title{
Social and legal aspects of non-alimony towards children in Poland
}

DOI: $10.5604 / 01.3001 .0014 .4353$

\author{
SYLWIA RÓŻYCKA-JAROŚ \\ Institute of Social Prevention and Resocialization \\ University of Warsaw \\ s.rozycka-jaros@uw.edu.pl
}

\begin{abstract}
Non-payment of alimony by parents for their children is a serious problem in Poland, which has negative social and economic consequences. It results in the inability to satisfy the necessary needs for their proper development and thus deprives them of prospects and a chance for a dignified life. This article begins by explaining the concept of non-alimony and presenting the scale of the phenomenon to gain awareness of the size of this social problem. In the following part, an analysis was carried out on the social aspects of non-alimony. This issue was described from the point of view of the situation of mothers who were forced to take over the entire burden of supporting their children, without the support of former partners. The consequences of the economic abandonment of children by one of the parents are also presented. The social aspect has also been discussed through the prism of the social campaigns conducted over the last few years to shape the correct attitudes of parents. Due to the fact that in Poland the phenomenon of non-alimony is considered primarily in the legal context, the subsequent part of the article presents a synthetic analysis in this respect. It focuses on the changes that the Polish legislator has introduced into the domestic legal system over the last 3 years. The discussion of this issue began with the offence of non-alimony regulated in Article 209 of the Penal Code, due to its amendment in 2017. It was supposed to become an effective tool to mobilise obliged parents to fulfil their obligation to support their children. Further amendments to the legislation were also reviewed in order to further improve the effectiveness of the enforcement of maintenance support.
\end{abstract}

Keywords: alimony, child, Article 209 of the Penal Code, alimony debtor 


\section{Introduction}

The obligation of parents to pay of maintenance to their children have been regulated in detail in Polish family law. According to the provisions of the Family and Guardianship Code, parents have the right and the obligation to care for their child (Article $95 \S 1$ ). This obligation is fundamental and cannot be relieved of. Moreover, article 133 of the Family and Guardianship Code expressly shows that parents are obliged to provide alimony to a child who is not yet able to support himself independently. It's the parents in the first place to provide the child with means of support. This obligation applies equally to both parents (Art. $93 \S 1)$. It does not matter whether they live together or separately, and with which parent the child lives together. It is therefore legally unacceptable and morally reprehensible if one of them evades the obligation to pay for the child only because his or her relationship with the other parent has broken down, he or she does not live with the child or claims to have financial difficulties resulting from unemployment. Family law does not directly use the concept of non-alimony but nevertheless, this is how the phenomenon of non-payment of maintenance by parents for their children is commonly called. The concept of non-alimony also functions in criminal law and means the offense of the perpetrator evading his maintenance obligation (209 of the Penal Code).

The scale of the problem related to non-payment of maintenance support in Poland is overwhelming. It is estimated, that almost a million children do not receive it from their parents (Ciszak, 2019). Only those children who are brought up in the poorest families can count on state support. Under the conditions set out in the Act of September 7, 2007 on assistance, persons entitled to alimony are granted benefits from the so-called the alimony fund. The right to benefit from the alimony fund depends on the income criterion. Currently, these benefits are paid if the family's monthly income per person does not exceed PLN 800 (Art. 9 (2)). Previously, for 11 years, the income threshold was only PLN 725. The maximum amount of the benefit from the alimony fund may not exceed PLN 500 per month (Art. 10 (1)). Over $24 \%$ of families receiving benefits from the alimony fund did not receive any income within the meaning of the provisions of the Act. The second largest group of families were those whose income did not exceed PLN 252 per person (34.7\% of families). (Information on the implementation of the Act on assistance to persons entitled to alimony in 
2015, 2016). It is estimated that about one third of non- alimony children benefit from the state Alimony Fund (Ciszak, 2019). The remaining children, over 750,000, are left without any support (Ambroziak, 2019).Currently, over 301,000 people do not pay their maintenance obligations. Polish parents in total owe their children an exorbitant amount of over PLN 12 billion. Interestingly, parents aged 36-45 are the leaders in avoiding payment, i.e. those who should theoretically be in the best professional situation. They constitute a group of over 100,000 debtors who are in arrears with alimony for a total amount of PLN 4.8 billion (Matłacz, 2019). Non-payment of maintenance support is definitely the domain of fathers who account for $95 \%$ of all maintenance debtors (BIK, 2018).

The insufficient level of collection of alimony through execution is a huge problem. According to the National Council of Bailiffs, bailiffs are able to enforce only $19 \%$ of the debt annually (CATIBUS survey report, 2017). Such low effectiveness of bailiff enforcement is the result of a number of actions taken by debtors to evade payment of maintenance support. In the opinion of parents who are struggling to support their children on their own, the most frequently indicated reasons for ineffective bailiff enforcement include the debtor's concealment of his or her assets $(75 \%)$ or difficulties in establishing his or her place of residence (43.6\%) (Żukowska - Gołębiewska, 2018). Interestingly, studies on the perception of those who fail to pay alimony show that in the opinion of the surveyed mothers struggling with the problem of non-payment of maintenance support by their former partners, over $73 \%$ of them are economically active. Some of them, however, work in the so-called "grey economy", have gone abroad or are engaged in business that is officially registered for another person. There are also still cases of deliberate lowering of income on a contract of employment within legal employment. This means that maintenance debtors, in the vast majority of cases, have the financial capacity to regularly support their children, but they deliberately avoid this (Żukowska - Gołębiewska, 2018).

\section{The social dimension of non-alimony}

A phenomenon worth noting in the context of non-alimony is that parents who face problems resulting from a lack of alimony alone do not feel adequately supported by the institutions set up to provide assistance to them. There is also a lack of understanding on the part of society 


\section{PAPERS OF SOCIAL PEDAGOGY 1/13, 2020: 67-87}

that non-alimony is de facto economic violence against children. In a 2018 survey on the perception of parents avoiding the payment of alimony, $74.6 \%$ of single parents claimed that police officers, prosecutors, judges and other officials do not treat this phenomenon as a serious problem. $69.7 \%$ of respondents indicated that the ineffectiveness of bailiff executions results from bailiffs' failure to use all available enforcement tools (Żukowska - Gołębiewska, 2018). Over $72 \%$ of the respondents were also of the opinion that the key reason for nonpayment of maintenance support is the employment of persons obligated in the so-called "grey economy". Nearly $60 \%$ of the respondents shared the sad reflection that in our country there is a low social awareness of the negative effects of non-alimony. Polish society is more inclined to negative assessment of people "fighting" for alimony payment than those who make every effort not to pay it. What is more, the average debtor usually has people around them supporting in the process of non-alimony. This group most often includes their parents (58\%), a new partner (50\%) or the employer (31\%) (Żukowska - Gołębiewska, 2018). 60\% of the mothers surveyed believe that non-alimony is socially acceptable, and people usually think it's not their problem and they shouldn't interfere $(64.1 \%)$. Only 5\% of the respondents considered that the Polish society really condemns the phenomenon of evasion of maintenance support payment (Żukowska - Gołębiewska, 2018). A slightly different picture emerges from a survey commissioned by the National Debt Register BIG S.A. and the National Council of Bailiffs in May 2017. The surveys showed that less than $74 \%$ of the respondents negatively assess the behaviour of parents who evade the payment of maintenance support and do not find understanding for this type of attitude. However, the lack of justification for non-alimony is not accompanied by a more active social attitude. Over $40 \%$ of respondents admitted that they never tried to influence the behaviour of a person avoiding paying alimony (Report from the survey CATIBUS, 2017). The majority of respondents considered the conviction of debtors of their own impunity as the reason for nonalimentation. Such an attitude of debtors, in their opinion, results mainly from too low penalties $(80 \%)$, insufficient use by gminas of tools at their disposal, e.g. in the field of professional activation of debtors (75\%) and the awareness of the lack of sufficient tools to collect outstanding debts by bailiffs (65\%). It should be considered symptomatic that as many as $75 \%$ of the surveyed were of the opinion that maintenance support debtors are guided by bad will and have a consent to the non-payment of alimony from their nearest environment (62\%). (Report from the CATIBUS survey, 2017). 
The most obvious social effect of non-alimony towards children is the lack of money to meet their needs. Almost $70 \%$ of the mothers surveyed openly admitted that this phenomenon has a negative impact on their children's quality of life. Apart from the inability to cover all necessary expenses for the child, the effect of non-alimony also results in the necessity for mothers to take up several jobs. The difference in the social and material status of their children is also visible. They are exposed to the unpleasantness on the part of their peers. They also do not participate in various extracurricular activities such as school trips or organized holidays (Żukowska - Gołębiewska, 2018). However, the social effects affect not only children, but also their mothers. As it appears from the survey, 54\% are left completely alone in their problem. As many as $48 \%$ indicated that in order to pay for the expenses related to maintaining the child, they cannot afford to satisfy their own needs. In over $32 \%$ of those surveyed, chronic fatigue, lowering of mood or a feeling of helplessness are also very common. The result of working several jobs is a lack of time both for themselves and for the child. Due to the stress resulting from the fight for alimony, $1 / 4$ of the respondents had to use the help of a specialist, i.e. a psychiatrist or psychologist (Żukowska - Gołębiewska, 2018). Additionally, a phenomenon that accompanies non-alimony is the complete breaking of emotional bonds with the child. The surveyed mothers who take care of their children on a daily basis, indicated in as many as $58 \%$ of the cases that fathers have no desire to contact with their children. This means that it is not uncommon for fathers to abandon their children not only in the material but also emotional sphere (Żukowska - Gołębiewska, 2018).

Summarizing the above issue, it should be clearly indicated that the problem of non-alimony has a number of negative consequences, both in economic and social terms. They affect both entitled children as well as those parents who bear all the costs of their maintenance. Undoubtedly, this should be counteracted, among others, by changing the mentality of Polish society. It is necessary to truly understand the consequences of the reprehensible attitude of alimony debtors and to provide support and assistance for both children and parents who face lone parenthood on a financial level.

The analysis of activities undertaken to shape public opinion indicates the need to conduct a permanent nationwide campaign to make the Polish society aware of the fact that nonpayment of maintenance support by one of the parents harms children. Publicizing the problem of non-alimony by organizing a nationwide social campaign could contribute to 


\section{PAPERS OF SOCIAL PEDAGOGY 1/13, 2020: 67-87}

achieving the desired change in the form of increasing the level of alimony payments. Moreover, reliable knowledge of the effects of this phenomenon would probably reduce social consent to non-payment of maintenance support.

Meanwhile, apart from subsequent changes in legislation, government institutions do not run any programmes raising Poles' knowledge about the phenomenon of non-alimony. The last information campaign, entitled "Responsible Parent pays", was conducted in autumn 2016 on the initiative of the Ministry of Family, Labour and Social Policy. As part of the campaign, a spot was prepared informing parents about the need to meet their alimony obligations in the form of an animated film, which was posted on the Ministry's website and on You Tube. A series of articles on the problem of non-payment of maintenance support in Poland and informing about their enforcement capabilities was also launched. The Ministry also addressed the issue in social media (Gov.pl., 2016). Despite the announcement of its continuation, the information campaign has not been launched in the following years. Meanwhile, the need to carry out a social campaign of a nationwide character was often pointed out by the Ombudsman of Civil Rights and the Ombudsman of Children's Rights. The Ombudsmen pointed out how important it is for such a campaign to attempt to change stereotypes about non-alimony in Poland. In their opinion, Polish citizens should be systematically made aware that maintenance support should be paid for the benefit of the child and that non-payment is nothing else but a form of economic violence. However, the interventions of the Ombudsmen in this matter in the Ministry of Family, Labour and Social Policy did not bring any results (Rpo.gov.pl, 2016).

At present, social initiatives to improve the situation of Polish children in terms of paying them alimony are undertaken primarily by non-governmental organizations. These organizations include the Association for the Improvement of Maintenance Issues "DlaNaszychDzieci" (For Our Children), which was founded in December 2014 on the initiative of single parents without financial support. The main objective of the association is to improve the effectiveness of alimony collection and to abolish the income criterion entitling children to receive alimony from the alimony fund. (Dlanaszychdzieci.com.pl, 2020). The Association regularly tries to organize various types of awareness raising actions. One of the first nationwide actions was to encourage opposition to economic violence as part of the campaign entitled "Alimenty to nieprezenty" (Alimony is not a gift). It consisted in collecting 
signatures under the petition to the Ministry of Family, Labour and Social Policy in order to undertake comprehensive actions aimed at improving the situation of children who do not receive alimony. The first collection of signatures took place in December 2015. As a result of the action, the Minister of Family, Labour and Social Policy received more than 10 thousand signatures collected throughout Poland on the issue of abolishing the threshold for assistance from the alimony fund. The action was continued from 24 October 2016 to 24 November 2016 under the name "Alimenty to nieprezenty - Round two". (Dlanaszychdzieci.com.pl, 2016).

An example of another initiative of the Association is a run against economic violence, which was first organized in Łódź on 8 March 2017 in cooperation with the Chamber of the Bailiffs. The event was held under the motto "Alimony - I pay because I care. I pay because I love"(Dlanaszychdzieci.com.pl, 2017).The project entitled "We are changing social awareness in the case of non-alimony", which was carried out in 2019, is also noteworthy. As part of this project, members of the Association organized free and public workshops on economic violence, including non-alimony, in smaller towns. They also benefited from the support of local Social Welfare Centers and local non-governmental organizations. Their aim was to provide up-to-date knowledge on changes in the law in the area of alimony and to conduct a social campaign on responsible parenthood (Report on the activities of the Alimony Team in 2019, 2020).

There are also a number of other non-governmental organizations in Poland which, in their statutory purposes, indicate actions aimed at improving the situation of children aggrieved by non-alimony. Their initiatives are most often financed from their own resources, donations and $1 \%$ provided by taxpayers. They are local, not nationwide. An important project in the field of monitoring the problem of non-alimony is the establishment of the Alimony Expert Team at the beginning of 2016 thanks to the joint initiative of the Ombudsman of Civil Rights and the Ombudsman of Children's Rights. Apart from the representatives of both Ombudsmen, the team includes lawyers, judges, a representative of the Lewiatan Confederation, representatives of the "For Our Children" Association, a representative of the "Debt Support Program" Association, as well as representatives of the world of science and the penitentiary environment. The first meeting of its members took place at the Office of the Obudsman of Civil Rights on February 9, 2016. The team undoubtedly reintroduced the issue 
of non-payment of maintenance support into the public debate. It developed, promoted and presented to the relevant authorities proposals for a campaign to change the social perception of alimony. It also largely contributed to changes in the law, which are described later in the article. (Rpo.gov.pl, 2016).

\section{The offence of non-alimony in Polish criminal law}

\section{Legal status before 2017}

The basic tool for combating the phenomenon of non-alimentation from the point of view of criminal law is Article 209 of the Penal Code. Before the entry into force of its amendment on 31 May 2017, the essence of the offence under Article 209 of the Penal Code consisted in the persistent evasion of payment of maintenance support to a person entitled to it. As a result of this act, such a person was exposed to the inability to satisfy his or her basic life needs (Bojarski, 2016). According to the Supreme Court's position, an offence took place when the obliged person, having an objective possibility of performing the alimony obligation, did not fulfill it out of bad will. Persistent evasion meant prolonged proceedings characterized by tenacity (Supreme Court judgment, 1979). For the determination of the offence of nonalimentation it was therefore not enough to establish that the obliged person did not pay alimony. It was also necessary to prove that he or she evaded this obligation "persistently", manifesting his or her bad will (Supreme Court judgment, 1996). For many years, therefore, the existence of an offence under Art. $209 \S 1$ of the Penal Code was determined by the characteristic of stubbornness. The result of the offence of non-alimony was the exposure of the affected person to the inability to meet their basic life needs (Giezek, 2014). The higher the degree of development of the society, the greater and more varied the needs were to be considered as basic (SC Resolution, 1976). The assessment of what constitutes the basic life needs was a source of interpretation problems. The realization of the signs of the deed under Art. $209 \S 1$ of the Penal Code was in the case of exposure of a child to the inability to satisfy his/her basic but not all life needs (Decision of the AC in Katowice, 2005). Moreover, in the doctrine, the view that failure to fully meet the maintenance obligation, e.g. paying alimony in a smaller amount than that awarded due to loss of job, or paying it irregularly due to the lack of a stable income, did not exhaust the features of the prohibited act under Article $209 \S 1$ of 
the Penal Code (the Katowice AC ruling, 2005). Therefore, it was common practice for obliged persons to pay symbolic amounts for alimony occasionally. Thus, at the time when the preparatory proceedings were initiated, about $50 \%$ of the cases ended up being a case discontinuance. This is reflected in the police statistics presented below.

Table no. 1. Statistics on crimes under Art. 209 of the Penal Code at the stage of preparatory proceedings

\begin{tabular}{|c|c|c|}
\hline Year & Number of proceedings initiated & Number of offences found \\
\hline 2006 & 16539 & 9982 \\
\hline 2016 & 16009 & 9398 \\
\hline
\end{tabular}

Source: Police statistics, 2020

It is also worth paying attention to the court statistics for the same period presented below.

Table no. 2. Statistics on crimes under Art. 209 of the Penal Code at the stage of court proceedings

\begin{tabular}{|c|c|c|c|c|}
\hline Year & $\begin{array}{c}\text { The jailed total } \\
\text { number }\end{array}$ & $\begin{array}{c}\text { The convicted } \\
\text { (share in \%) }\end{array}$ & $\begin{array}{c}\text { Discontinuation of } \\
\text { proceedings } \\
\text { (share in \%) }\end{array}$ & $\begin{array}{c}\text { Found not guilty } \\
\text { (share in \%) }\end{array}$ \\
\hline 2006 & 13356 & $12336(92,4 \%)$ & $785(5,9 \%)$ & $228(1,7 \%)$ \\
\hline 2016 & 8841 & $8499(96,1 \%)$ & $241(2,7 \%)$ & $94(1,1 \%)$ \\
\hline
\end{tabular}

Source: Statistical reports MS-S6r. (Statistical picture of the offence of evasion of the execution of the maintenance support obligation (Article 209 of the Penal Code), 2019

Table no. 3. Statistics on penalties adjudicated for the crime under Art. 209 of the Penal Code

\begin{tabular}{|l|l|l|l|l|l|l|}
\hline Year & $\begin{array}{l}\text { Total } \\
\text { convictions }\end{array}$ & $\begin{array}{l}\text { Absolute } \\
\text { imprisonment }\end{array}$ & $\begin{array}{l}\text { Imprisonment } \\
\text { with conditional } \\
\text { suspension }\end{array}$ & $\begin{array}{l}\text { Restriction of } \\
\text { freedom }\end{array}$ & $\begin{array}{l}\text { Solely- } \\
\text { imposed } \\
\text { fine }\end{array}$ & $\begin{array}{l}\text { Mixed } \\
\text { penalty }\end{array}$ \\
\hline 2006 & 12336 & $489(80,9 \%)$ & $9494(77,0 \%)$ & $2191(17,8 \%)$ & $162(1,3 \%)$ & No \\
\hline 2016 & 8499 & $1281(440 \%)$ & $2455(28,9 \%)$ & $4247(50,0 \%)$ & $455(5,4 \%)$ & 59 \\
\hline
\end{tabular}

Source: Statistical reports MS-S6r. (Statistical picture of the offence of evasion of the execution of the maintenance support obligation (Article 209 of the Penal Code), 2019 
The analysis of data shows that between 2006 and 2016, there was a significant increase in the restriction of liberty sentences imposed by courts (from 17 to 50\%), as well as the resignation of imprisonment with conditional suspension, which for most years accounted for $70 \%$ of all sentences imposed. For years, maintenance support debtors did not feel any significant hardship from the Polish justice system. In many cases their case was discontinued at the pretrial stage or, if the indictment was sent to court, the sentence of imprisonment with conditional suspension was announced. No wonder that the prospect of punishing the alimony debtor under Article 209 of the Penal Code, has not contributed in any way to changing his or her conduct and, consequently, the effective enforcement of maintenance support.

\section{Amendment of regulations and its effects (Article 209 of the Penal Code)}

Legislator in Poland decided to significantly change the perception of the problem of nonalimony from the point of view of criminal law. In the current legal status, the feature of persistence has been abandoned. For the existence of an offense under Art. $209 \S 1$ of the PC, it is only necessary for the total amount of arrears to be the equivalent of at least 3 periodical benefits or a benefit for a period of at least 3 months (Mozgawa, 2020). In the basic type of this offence, there is also no feature of exposing the entitled person to the inability to meet basic life needs. Instead, a qualified type of offense of non-alimony has been established. Therefore, the offense of non-alimony is penalized more severely if the entitled person is actually exposed to the inability to meet basic life needs (Konarska-Wrzosek, 2018; Justification of the government bill amending the Act - Penal Code, 2017). A new legal solution is the possibility of avoiding a penalty in the case of paying the outstanding alimony in full. The maintenance support debtor is not punished if, within 30 days from the date of the first hearing as a suspect, he or she has paid it in full. Moreover, the court has the right to refrain from imposing the penalty if, not later than within 30 days from the date of the first hearing as a suspect, the perpetrator of the offense of non-alimony in the qualified type has fully paid the arrears of maintenance support. The purpose of these provisions is to effectively mobilize debtors to pay the arrears of maintenance support (Justification of the government bill amending the act - Penal Code, 2017).

The first effect of the changes resulting from the described amendment to the PC was the rapid increase in applications that were received by the authorities in the area of prosecuting 
crimes under Art. 209 of the CC. This is demonstrated by the prosecution data presented by the Institute of Justice.

Table no. 4. Statistics on crimes under Art. 209 of the Penal Code at the stage of preparatory proceedings

\begin{tabular}{|c|c|c|c|}
\hline Specification & 2016 r. & 2017 r. & 2018 r. \\
\hline Inflow of cases & 27976 & 57596 & 156502 \\
\hline Initiated proceedings & 18017 & 40797 & 118040 \\
\hline Proceedings completed - total & 26804 & 43509 & 161525 \\
\hline - $\quad$ including indictment & 5094 & 11225 & 51992 \\
\hline - $\quad$ application for a conviction & 2863 & 2422 & 7511 \\
\hline $\begin{array}{l}\text { - application for conditional discontinuance of } \\
\text { proceedings }\end{array}$ & 100 & 129 & 567 \\
\hline - discontinuation & 7576 & 11329 & 49236 \\
\hline - denial of initiation & 9658 & 16223 & 33683 \\
\hline - $\quad$ suspension & 723 & 1990 & 17930 \\
\hline - other ways of completion & 790 & 191 & 606 \\
\hline
\end{tabular}

Source: Data of the National Prosecutor's Office on the basis of SIP LIBRA 2,5. (Statistical picture of the offence of evasion of the execution of the maintenance support obligation (Article 209 of the Penal Code), 2019

The most authoritative comparison is that of 2016, the year in which Art. 209 of the PC was in force in its previous version with 2018, which was the first full year of the new regulations. As the above- mentioned data show, there was more than a five-fold increase in the number of cases which were submitted to law enforcement authorities. More than six times more proceedings were instituted, which ten times more often resulted in filing a bill of indictment to the court. Looking at the above- mentioned numbers, it may be concluded that at present it is much more difficult for an offender who evades payment of maintenance support obligations to avoid liability. Therefore, it would seem that the amendment of Article 209 of the Penal Code has had its first positive effect. A further analysis of the remaining available data does not arouse such enthusiasm. It should be noted that alimony debtors are most often sentenced to the penalty of restriction of liberty, which usually takes the form of socially useful work. This penalty is imposed in more than $68 \%$ of cases. 
Table no. 5. Statistics on penalties adjudicated for the crime under Art. 209 of the Penal Code

\begin{tabular}{|l|l|l|l|l|l|l|}
\hline Year & $\begin{array}{l}\text { Convictions } \\
\text { total }\end{array}$ & $\begin{array}{l}\text { Absolute } \\
\text { imprisonment }\end{array}$ & $\begin{array}{l}\text { Imprisonment } \\
\text { with } \\
\text { conditional } \\
\text { suspension }\end{array}$ & $\begin{array}{l}\text { Liberty } \\
\text { restriction }\end{array}$ & $\begin{array}{l}\text { Solely- } \\
\text { imposed fine }\end{array}$ & $\begin{array}{l}\text { Mixed } \\
\text { penalty }\end{array}$ \\
\hline 2017 & 8654 & $1391(37,3 \%)$ & $1840(21,3 \%)$ & $4840(55,9 \%)$ & $543(6,3 \%)$ & 39 \\
\hline 2018 & 45068 & $5210(23,3 \%)$ & $5272(11,7 \%)$ & $30782(68,3 \%)$ & $3693(8,2 \%)$ & 109 \\
\hline
\end{tabular}

Source: Statistical reports MS-S6r (Statistical picture of an offence of evasion of the execution of a maintenance support obligation (Article 209 of the Penal Code), 2019

It is not difficult to guess that debtors sentenced under Art. $209 \S 1$ of the Penal Code to socially useful work are not sufficiently motivated to return the alimony arrears that have arisen and to settle their obligations on an ongoing basis.

The most recent data from the National Debt Register indicate that in 2019, parents obliged to pay maintenance support payments to their children were indebted to them in total PLN 12.3 billion, with this debt still amounting to PLN 11.8 billion in July 2019, and four years earlier it was twice as low, i.e. PLN 5 billion. One debtor has a debt in the amount of PLN 40.7 thousand. In 2015 it was on average 29 thousand PLN (Matłacz, 2019). It should also be mentioned that after the tightening of the provisions of the Penal Code in 2017, the number of debtors listed in the National Debt Register decreased. In 2017, it was 324 thousand people, a year later - 312 thousand, and in 2019 - 301.2 thousand. However, this cannot be considered a success resulting from the introduced legal regulations because in fact the amount of arrears, as shown by the above- mentioned data, has increased (Matłacz, 2019). This is due to the fact that maintenance support debtors who are still listed in the National Debt Register do not settle both past and present maintenance obligations.

The Ministry of Justice is of the opinion that the changes introduced have brought the desired results. Comparing the collection of alimony arrears with the amounts of payments from the alimony fund, it has calculated that from 2015 the enforcement of alimony has increased from $13 \%$ to $34 \%$. Other data are provided by the National Council of Bailiffs. Their estimates show that the collection of alimony debts since 2012 has remained at the same level and amounts to about $19 \%$. At this point it is worth noting that the number of persons entitled to 
receive benefits from the alimony fund has been constantly decreasing in recent years. In 2012 it was used by 339.5 thousand children. In the first quarter of 2019, even before the income criterion was raised from PLN 725 to PLN 800, the lowest result in the history of the fund was recorded. Only 241 thousand people received money (Ambroziak, 2020). The above data, in principle, means that the collection rate is not so much increasing as the burden on the fund itself is gradually decreasing. However, taking into account the fact that the income criterion has been raised, we can expect an increase in the number of people entitled to receive benefits from the alimony fund.

In the opinion of non-governmental organisations and the Ombudsman of Civil Rights, the courts make insufficient use of the possibility of imposing a custodial sentence on alimony debtors, enforced by electronic supervision. This solution does not expose the state to additional costs of living for the prisoner. In addition, electronic supervision allows the debtor to take up work and, consequently, the payment of the alimony debt. Meanwhile, according to the information obtained by the Office of the Ombudsman from the Office of Electronic Surveillance of the Central Board of the Penitentiary Service, the number of non-alimony convicts who started serving their sentences in the electronic surveillance system after the change of the Code is lower than before. In the period from 31 May 2016 to 31 May 2017 it amounted to 1166 persons and from 31 May 2017 to 7 May 2018 it decreased to 1087. According to the data of August 2019, electronic supervision was applied only to 801 persons. As of 25 February 2020, only 945 persons are serving prison sentences for this act in the electronic system (rpo.gov.pl, 2020). It should be emphasized that there are currently 12-14 thousand convicted and obliged to alimony in prisons, including 5075 persons sentenced only under Article 209 of the Penal Code. Alimony sent from a penitentiary institution amounts to PLN 200 per month on average. While in prison, the alimony debts are still growing. Therefore, the situation of both the debtor and the person entitled to alimony does not improve. (rpo.gov.pl, 2020).

\section{Legal solutions introduced and designed and their social impact}

When discussing the issue of non-alimony, one should mention the comprehensive regulation, which introduced a number of new solutions. They are aimed at improving the efficiency of 
enforcing maintenance support payments and eliminating undesirable phenomena in the form of deliberate evasion of this obligation by concealing income and assets. On December 6, 2018, the Sejm adopted the Act amending certain regulations to improve the effectiveness of the enforcement of maintenance support payments. This act implements the so-called alimony package contained in the document adopted in March 2017 by the Council of Ministers "Review of family support systems" (gov.pl, 2017; justification of the government draft Act amending certain regulations to improve the effectiveness of the enforcement of maintenance support benefits, 2018). It is still difficult to assess the effectiveness of the implemented changes because the act, with some exceptions, entered into force on January 11, 2019, but undoubtedly the chosen direction seems to be right. The legislator focused primarily on creating solutions aimed at improving the flow of information between relevant services and institutions and court bailiffs. Appropriate changes were introduced to the Act on the social insurance system. They are used to more efficiently obtain by court bailiffs up-to-date information on the income obtained by alimony debtors based on data from the Social Insurance Institution. Court bailiffs can quickly obtain in electronic form current information on alimony debtors in terms of their employment, change of employment and thus - achieved income (Art. 50 (9), 20, 21).

Undoubtedly, the financial sanctions for the illegal employment of workers against whom maintenance support payments are pending are a great change. The employer may be fined from PLN 1,500 to PLN 45,000. This will happen in the case of employment of a alimony debtor without confirmation in writing of the employment contract concluded with him or her, and also in a situation where they will be paid a remuneration higher than that resulting from the concluded contract for employment, without making any deductions for payment of maintenance support benefits (Justification of the government bill amending certain acts to improve the effectiveness of the enforcement of maintenance support payments, 2018). The above-mentioned regulations will come into force on 1 December 2020, but it can already be foreseen that the possibility of imposing a high fine should have a demotivating effect on employers who employ alimony debtors in the gray economy or pay them remuneration "under the table".

In terms of increasing the effectiveness of the enforcement of maintenance support claims, another change has been introduced, consisting in the introduction of the possibility of 
carrying out enforcement from 50\% of the amount of allowances due for business trips. It should be clarified here that before the entry into force of these amendments, the amounts intended to cover expenses or business trips were not subject to enforcement. This change is important because the work of some maintenance debtors is associated with business trips e.g. professional drivers in international traffic. They often get paid at the minimum or slightly higher wages for their work. At the same time, they additionally receive sums to cover expenses or business trips in the amount many times exceeding the amount of remuneration (Justification of the government bill amending certain acts to improve the effectiveness of the enforcement of maintenance support payments, 2018). The bailiffs were therefore able to seize additional funds to cover alimony obligations.

The legislator also introduced changes to the Executive Penal Code concerning alimony debtors who were imposed a penalty of restriction of liberty in the form of electronic supervision. They consist in the possibility of making data about the place of stay of convicts available to the National Labor Inspectorate and court bailiffs. Thanks to this solution, NLI obtained an additional tool to verify whether debtors, who often indicate unemployment, do not work in the gray economy, and bailiffs - the possibility of enforcing outstanding alimony (Art. 43ga).

By introducing changes to the Act on Employment Promotion and Labor Market Institutions, the legislator also decided to professionally activate alimony debtors, who often cite unemployment as the reason for failure to meet their obligations. For this purpose, public works were used, which are one of the labor market instruments of a socially useful nature. The obligation of employment of alimony debtors was imposed on the organizer of public works (Art. 56 a). This means that people with alimony debts have priority of the right to employment in this form. (Art. $108 \mathrm{sec} .2 \mathrm{a}$ ).

After many years, we also saw a change in the amount of the income criterion entitling to benefits from the alimony fund. From October 1, 2008 to September 30, 2019, benefits from the fund were only payable if the family income, per person, did not exceed PLN 725. From October 1, 2019, benefits from the fund are paid if the family income per person does not exceed PLN 800. The legislator estimated that thanks to the increase in the income criterion, additional 60,000 children will benefit from the alimony fund (Justification of the government 
bill amending certain acts to improve the effectiveness of the enforcement of alimony payments, 2018).

Currently, debtors who fail to meet their maintenance support obligations are entered in the Register of Insolvent Debtors. However, only debtors for which bailiff enforcement has proved ineffective with regard to maintenance support arrears for a period longer than 6 months are listed here. The access to the register is not simple and fast enough, therefore the entry in it did not increase the collection of alimony. On December 1, 2020, the Act of December 6, 2018 on the National Register of Debtors will enter into force. From that date, the Register of Insolvent Debtors will be replaced by a fully open and publicly available National Register of Debtors (Art. 4). It will disclose information, e.g. on persons against whom enforcement of maintenance support payments or state budget receivables due to payments made from the alimony fund is pending. It is enough for the arrears to be longer than 3 months (Art. 2, section 1, point 4). Data on persons in arrears with the payment of alimony will automatically cease to be disclosed only after 7 years from the completion of enforcement proceedings or payment of the entire amount due (Art. 11 (7)). The legislator hopes that the entry in the new register will motivate debtors to fulfill their obligations to a greater extent due to its full transparency (gov.pl, 2018).

The previous term Parliament in Poland also took steps to comprehensively change the law in terms of strengthening the protection of children's rights in the event of the break-up of parents' marriage. It referred to diagnosed problems in the field of alimony and ensuring contacts with parents within the so-called alternate care. The regulations planned at that time (Sejm Print 3254, 2019) were to introduce an institution of immediate alimony and ordered alimony proceedings, unknown to Polish legislation. The amount of the benefit was to be standardized and calculated according to a special algorithm taking into account the minimum wage and the fertility rate. The benefit was to secure the material well-being of children and constitute an alternative to the prolonged traditional proceedings in cases for maintenance support. At the same time, it was intended to introduce automatic expiry of the child support entitlement when the child turns 25 . Collecting the so-called "immediate alimony" would not exclude applying for maintenance in the normal course (Assessment of the effects of regulations contained in the government bill amending the Act - Family and Guardianship Code and other acts, 2019). As a result of the discontinuation of the work of the previous 
parliament, the project to introduce the so-called "immediate alimony" alimony was lost. There is no doubt, however, that in the current term of office it would be advisable to return to the previously proposed solutions. Both the Ombudsman of Civil Rights (Rpo.gov.pl, 2020) as well as the Ombudsman of Children's Rights are seeking to do so (Brpd.gov.pl, 2020).

\section{Conclusion}

In Poland, the main emphasis in terms of preventing non-alimony is placed on introducing changes in legislation that will more effectively "force" parents to meet their obligation to contribute financially to their children. A synthetic legal analysis made in this article indicates how many changes the Polish legislator has introduced into the domestic legal system in the last 3 years. The period of intensive checking of the effects, which should gradually begin to have the desired consequences, is ahead of us. In the nearest future, we will probably see further legal solutions aimed at protecting Polish children, among others, in the context of securing their financial situation through effective enforcement of maintenance support payments due to them.

The public debate focuses only on the problem of unpaid alimony, instead of taking into account the important cultural aspect of the phenomenon. This results in a lack of effective actions which on a national scale would lead to an increase in awareness and a change in perception of the problem described. No legal regulations will sufficiently protect the youngest if their parents, especially fathers, do not start to see the need to support them from the right perspective, and feel like a rightful parent, responsible for their fate and conditions. In addition to legislative changes, it is therefore more important to develop appropriate social attitudes to understand how conscious and responsible parenthood on the part of both parents is crucial for the child's development. The drive to strengthen the bond between fathers and children can be based on mechanisms involving them more in caring for them. An example of such activities may be, for example, more effective encouragement of fathers to take the leaves due to them with the birth of a child. It is also important to carry out ongoing educational activities aimed at the general public, as well as unsupportive parents, groups that assist them and staff of public institutions and the judiciary. These activities could make a 
significant contribution to greater sensitivity and understanding of the real nature of the problem.

\section{References}

Ambroziak, A. (2019), A horrible record: more than 750,000 children without money from the Alimony Fund, [online], Available at: https://oko.press/straszny-rekord-ponad-750-tys-dziecibez-pieniedzy-z-funduszu-alimentacyjnego/ (Accessed 24 April 2020)

Ambroziak, A. (2020), Polish shame. Deadbeat dads already have 12.3 billion PLN of debt [online], Available at: https://oko.press/polski-wstyd-alimenciarze-maja-juz-123-mld-zl-dlugu/ (Accessed 25 April 2020)

Office of Credit Information, Report - Alimony Debtor (2018), Available at:https://media.bik.pl/publikacje/read/397423/raport-dluznik-alimentacyjny-lipiec-2018/ (Accessed 25 April 2020)

Bojarski, T. (2016), (ed.), Penal Code. Comment, issue VII, Available at: https://sip.lex.pl/\#/commentary/587634661/489651/bojarski-tadeusz-red-kodeks-karnykomentarz-wyd-vii?cm=URELATIONS (Accessed 25 April 2020)

Brpd.gov.pl, (2020), Official website of the Children's Rights Ombudsman, [online], Available at: https://brpd.gov.pl/2020/04/24/rzecznik-praw-dziecka-apeluje-takze-dzieci-potrzebuja-tarczyantykryzysowej-wprowadzcie-alimenty-natychmiastowe/ (Accessed 27 April 2020)

Ciszak, P. (2019), Children of deadbeat dads without holiday money. Nearly one million children do not receive maintenance support, [online], Available at: https://www.money.pl/gospodarka/dzieci-alimenciarzy-bez-pieniedzy-na-wakacje-prawiemilion-nie-otrzymuje-alimentow-6397821774432385a.html/ (Accessed 24 April 2020)

Giezek, J. (2014), (ed.), Penal Code. Special part. Comment, Available at: https://sip.lex.pl/\#/commentary/587370915/168355/giezek-jacek-red-kodeks-karny-czescszczegolna-komentarz?cm=URELATIONS (Accessed 26 April 2020).

Dlanaszychdzieci.com (2017), Official Service of the Association for the Improvement of Maintenance Support Issues "For Our Children" Available at: http://dlanaszychdzieci.com/127-alimenty-płacę,- bo-dbam-płace,-bo- kocham (Accessed 26 May 2020)

Dlanaszychdzieci.com (2016), Official Service of the Association for the Improvement of Maintenance Support Issues "For Our Children" Available at: http://www.dlanaszychdzieci.com/24-przy\%C5\%82\%C4\%85cz-si\%C4\%99-do-naszychakcji/97-akcja-alimenty-to-nie-prezenty-runda-ii (Accessed 26 May 2020) 
Dlanaszychdzieci.com (2020), Official Service of the Association for the Improvement of

Maintenance Support Issues "For Our Children" Available at: (Accessed 26 May 2020):

http://dlanaszychdzieci.com/poznaj-nas/nasze-cele (Accessed May 26, 2020).)

Gov.pl, (2016), Official Service of the Republic of Poland, Available at:

https://www.gov.pl/web/rodzina/informacja-mrpips-o-przebiegu-akcji-odpowiedzialny-rodzicplaci (Accessed 26 May 2020)

Gov.pl, (2017), Official website of the Republic of Poland, Available at: https://www.gov.pl/web/rodzina/przeglad-systemow-wsparcia-rodzin (Accessed 26 April 2020)

Gov.pl, (2018), Official website of the Republic of Poland, Available at: https://www.gov.pl/web/sprawiedliwosc/dluznicy-alimentacyjni-w-krajowym-rejestrzezadluzonych (Accessed 26 April 2020)

Information on the implementation of the Act on assistance to persons entitled to maintenance support in 2015, Ministry of Family, Labour and Social Policy, 2016, p. 18, Available at: https://www.gov.pl/web/rodzina/realizacja-ustawy-o-pomocy-osobom-uprawnionym-doalimentow/ (Accessed 24 April 2020)

Institute of Justice, (2019), Statistical picture of the offence of evasion of the execution of a maintenance support obligation (Article 209 of the Penal Code), pp. 3-5, Available at: https://www.rpo.gov.pl/sites/default/files/odp\%20Instytutu\%20Wymiaru\%20Sprawiedliwo\% C5\%9Bci\%20-\%20alimenty\%202.04.2019.pdf/ (Accessed 25 April 2020)

Konarska-Wrzosek, V. (2018), (ed.), Penal Code. Commentary, Available at in LEX: https://sip.lex.pl/\#/commentary/587715865/571125/konarska-wrzosek-violetta-red-kodekskarny-komentarz-wyd-ii?cm=URELATIONS (Accessed 24 April 2020)

Matłacz, A. (2019), Fewer alimony debtors but their debtsare higher, [online], Available at: https://www.prawo.pl/prawo/dluznicy-alimentacyjni-w-krd-2019,496687.html/ (Accessed 25 April 2020)

Mozgawa, M. (2020) (ed.), Penal Code. Updated commentary, Available at: https://sip.lex.pl/\#/commentary/587737061/612103/mozgawa-marek-red-kodeks-karnykomentarz-aktualizowany?cm=URELATIONS (Accessed April 24th , 2020.)

Impact assessment of the regulations contained in the government draft amending the act - Family and Guardianship Code and certain other acts, 12.03.2019, Parliamentary Printing 3254, Available at the address: https://www.sejm.gov.pl/Sejm8.nsf/opinieBAS.xsp?nr=3254/

(Accessed 24 April 2020)

Decision of AC in Katowice of 12 January 2005, II Ako 1/05, KZS 2005, t.7-8, item 117 
Draft amending the Act - Family and Guardianship Code and certain other acts, VIII term of office, 27.02.2019, Sejm printing no. 3254, available at: https://www.sejm.gov.pl/Sejm8.nsf/PrzebiegProc.xsp?nr=3254/ (Accessed 25 April 2020)

Report from the CATIBUS survey for the National Debt Register BIG S.A. and the National Council of Bailiffs, 2017, Attitudes of Poles towards non-payment of alimony, pp. 6-7, 14, Available at: https://krd.pl/Centrum-prasowe/Raporty/Postawy-Polakow-wobec-nieplacenia-alimentow--raport/ (Accessed 25 April 2020)

Report on the activities of the Maintenance Support Team in 2019, 2020, p. 2, Available at: https://www.rpo.gov.pl/pl/content/sprawozdanie-zespolu-do-spraw-alimentow-za-rok-2019 (Accessed 27 May 2020)

Rpo.gov.pl, (2016), The official website of the Ombudsman of Civil Rights, Available at: https://www.rpo.gov.pl/pl/content/zesp\%C3\%B3\%C5\%82-ekspert\%C3\%B3w-dsaliment\%C3\%B3w (Accessed 26 May 2020)

Rpo.gov.pl, (2016), Official website of the Ombudsman of Civil Rights, Available at: https://www.rpo.gov.pl/pl/content/\%E2\%80\%9Eodpowiedzialny-rodzicp\%C5\%82aci\%E2\%80\%9D-rzecznicy-praw-obywatelskich-i-praw-dziecka-pytaj\%C4\%85ministra-rodziny-o (Accessed 26 May 2020)

Rpo.gov.pl, (2020), Official website of the Ombudsman of Civil Rights, Available at: https://www.rpo.gov.pl/pl/content/945-alimenciarzy-odbywa-kare-w-systemie-dozoruelektronicznego, (Accessed 26 April 2020)

Rpo.gov.pl, (2020), Official website of the Ombudsman of Civil Rights, Available at: https://www.rpo.gov.pl/pl/content/zespol-ekspertow-ds-alimentow-XI-posiedzenie, (Accessed 26 April 2020.)

Rpo.gov.pl, (2020), Official website of the Ombudsman of Civil Rights, Available at: https://www.rpo.gov.pl/pl/content/alimenty-natychmiastowe-rpo-pyta-czy-ms-dalej-pracuje (Accessed 26 April 2020)

Rpo.gov.pl, (2020), Official website of the Ombudsman of Civila Rights, Available at: https://www.rpo.gov.pl/pl/content/koronawirus-alimenty-stanowisko-rpo-i-zespolu-dsalimentow (Accessed 27 April 2020)

Statystyka.policja.pl, Official website for police statistics, Available at: http://www.statystyka.policja.pl/st/kodeks-karny/przestepstwa-przeciwko-7/63509,Uchylaniesie-od-alimentacji-art-209.html/ (Accessed 25 April 2020)

Resolution of the Supreme Court of 9 June 1976, VI KZP 13/75, OSNKW 1976/7-8, item 86, Act of 25 February 1964. - Family and Guardianship Code (Journal of Laws of 2019, item 2086) Act of 17 November 1964. - Code of Civil Procedure (Journal of Laws of 2019, item 1460) 


\section{PAPERS OF SOCIAL PEDAGOGY 1/13, 2020: 67-87}

Act of 17 June 1966 on enforcement proceedings in administration (Journal of Laws of 2019, item 1438)

Act of 26 June 1974. - Labour Code (Journal of Laws of 2019, item 1040)

Act of 6 June 1997. - Penal Code (Journal of Laws of 2019, item 1950)

Law of 6 June 1997. - Executive Penal Code (Journal of Laws of 2020, item 523)

Act of 13 October 1998 on the social security system (Journal of Laws of 2020, item 266)

Act of 20 April 2004 on employment promotion and labour market institutions (Journal of Laws of 2019, item 1482)

Act of 7 September 2007 on assistance to persons entitled to maintenance support (Journal of Laws of 2019, item 670)

Act of 23 March 2017 amending the Act - Penal Code and the Act on assistance to persons entitled to alimony (Journal of Laws of 2017. item 952)

Act of 6 December 2018 on the National Debt Register (Journal of Laws of 2019, item 55)

Act of 6 December 2018 amending certain acts to improve the effectiveness of the enforcement of maintenance support payments (Journal of Laws of 2018, item 2432)

Act on special arrangements for the prevention, counteraction and combating of COVID-19, other infectious diseases and the resulting emergencies (Journal of Laws of 2020, item 374 with later amendments).

Justification of the governmental bill on the amendment of the Act - Penal Code, (3.01.2017), VIII term of office, Sejm printing No. 1193, available at: http://www.sejm.gov.pl/Sejm8.nsf/druk.xsp?nr=1193/ (Accessed 25 April 2020)

Justification of the government bill to amend certain acts to Improve the enforcement of maintenance support, (30.10.2018), VIII term of office, Sejm Printing No 2987, Available at: http://search.sejm.gov.pl/SejmSearch/ADDL.aspx?DoSearchNewByIndex/ (Accessed 25 April 2020)

Judgment of the Supreme Court of 19 December 1979, V KRN 297/79, OSNPG 1980, No 6, item 79

Judgment of the SC of 27 February 1996, KRN II 200/95, Prok. and Pr.-wl. 1996, no. 10, item 8

Judgment of the SC of 3 July 2003, II KK 125/03, OSNwSK 2003, item 1458

Judgment of AC in Katowice of 13 January 2005, II AKa 455/04, KZS 2005, z. 7-8, item 118

Judgment of the AC in Wrocław of 16 March 2016, II AKa 7/16, LEX No 2025526

Żukowska-Gołębiewska, J. (2018), Research Report. Perception of persons not fulfilling the alimony obligation. Reasons for non-alimony in the psychosocial model, p. 8, 12-13, 15, 23-24, available at: https://www.rpo.gov.pl/sites/default/files/RAPORT\%20Z\%20BADANIA\%20DND.pdf (Accessed 25 April 2020). 